\title{
Comparative herbaceous phytosociology in agrofor- estry and Calophyllum brasiliense monoculture on a river terrace
}

Antonio Carlos Pries Devide ${ }^{1}$

Cristina Maria de Castro

Raul de Lucena Duarte Ribeiro ${ }^{3}$

Marcos Gervasio Pereira ${ }^{4}$

\section{Abstract}

Invasive forage grasses, especially the Urochloa genus, impact reforestation worldwide. The aim of this study was to evaluate management influence on phytosociology of the herbaceous layer, defined as the layer of herbs, sub-shrubs, shrubs and vines, in two agroforestry systems (AFS) (Simple and Biodiverse) in succession to a reforestation of guanandi (Calophyllum brasiliense), compared to monoculture of this specie taken as control. The experiment was conducted in Pindamonhanga (SP), Brazil, from 2011 to 2014, in a randomized block design with eight replications and $144.0 \mathrm{~m}^{2}$ plots. In Simple SAF area, food crops were grown alongside C. brasiliense rows: sweet cassava (Manihot esculenta) in rotation with arrowroot (Maranta arundinacea), pigeon pea (Cajanus cajan), banana shrub (Musa sp.), and juçara palm (Euterpe edulis). In Biodiverse AFS, fourteen native tree species were also planted alongside the food crops. Altogether 41 herbaceous layer species, 38 genera and 24 botanical families were identified; the most abundant families were: Asteraceae, Poaceae e Cyperaceae. The similarity between the areas diverged after three years of management, with the predominance of Commelina benghalensis and M. arundinacea in the AFS areas and Urochloa decumbens in the monocultive, mainly, due to the shadow gradient established for the three systems.

Keywords: Ecological reforestation; Biodiversity; Spontaneous plants.

\section{Introduction}

Inadequate agricultural systems can contribute to soil degradation, resulting in productivity loss and other environmental problems. In the Paraíba do Sul Valley, soil degradation has begun in coffee culture cycle and it has intensified by extensive livestock expansion (DEVIDE et al., 2014; SANTOS et al., 2016). From 1962 to 2011, forest cover increased in the sub-regions of the Paraiba River valley, it had gone up by $133.0 \%$ in the middle valley (most industrialized region) and by $77.0 \%$ in the high valley, a rural sub-region with a strong exodus, in addition to cattle herd reduction (SILVA et al., 2017). The impacts on the landscape resulted in $82.0 \%$ of this remaining natural forest coverage dispersed in small fragmented remnants with 20 hectares or less until 2005 (KRONKA et al., 2005), which is considered too small for biodiversity protection and highly vulnerable to invasive grasses. Currently, the most determining factors for natural forest regeneration are the small size and the large

1 Agência Paulista de Tecnologia dos Agronegócios, pesquisador. antoniodevide@apta.sp.gov.br. Av. Dr. Antônio Pinheiro Junior, 4009, Caixa postal 32, 12400-970 Pindamonhangaba (SP), Brasil.

2 Agência Paulista de Tecnologia dos Agronegócios, pesquisadora. cristinacastro@apta.sp.gov.br.

3 Universidade Federal Rural do Rio de Janeiro, professor do Curso de Pós-Graduação em Fitotecnia. lucena@ufrrj.br.

4 Universidade Federal Rural do Rio de Janeiro, professor do Curso de Pós-Graduação em Agronomia, Ciência do Solo. gervasio@gmail.com. 
distance of those forest remnants that are surrounded by 213 thousand hectares of pasture areas of high potential for ecological self-recovery and 113 thousand hectares of medium ecological self-recovery potential (SECRETARIA DO MEIO AMBIENTE, 2018).

The grasses species belong to the Poaceae family, which comprises approximately 790 genera and 10,000 species. In Brazil, approximately 200 genera and more than 1,350 species of Poaceae have been described (LONDE; SILVA, 2014). Infestation of non-native forage grasses, mainly of the genus Urochloa is one of the most important biological barriers for the restoration in tropical forests areas (GARCÍA-ORTH; MARTÍNEZ-RAMOS, 2011; MANTOANI; TOREZAN, 2016). Urochloa decumbens (Stapf) R. D. Webster is an exotic grass that has adapted to the tropical environment throughout Latin America as it is quite tolerant to high levels of aluminum prevalent in acidic soils (SEIFFERT, 1980). Forage grasses can increase fire intensity and native species suppression (CABIN et al., 2002, FLORY et al., 2015).

In commercial and regenerative reforestation, grass control is usually carried out by herbicides, to ensure satisfactory conditions for tree growth (CORDELL et al., 2004; PYWELL et al., 2010; MOORE et al., 2011). The large-scale use of chemicals in mountainous relief and in permeable soils can contaminate water resources and reach underground aquifers (BRITO et al., 2001; AGRAWAL et al., 2010; SOARES et al., 2012; MOREIRA et al., 2012; SOARES et al., 2013) and also reduce spontaneous species richness (CÉSAR et al., 2013). In reforestation of slow-growing native species, such as the guanandi tree (Calophyllum brasiliense Cambess.), chemical control can become costly and increase the impact on environment and on rural workers. C. brasiliense is a climax forest specie (BRENES; MONTAGNINI, 2006; PETIT; MONTAGNINI, 2006) that offers a noble wood; therefore, it is widely used for environmental restoration of flooded areas (DURIGAN, 1990; CARVALHO, 2003; BRENES; MONTAGNINI, 2006).

The diversification of forest plantations combined with intercropping crops in agroforestry systems (AFS) can be immensely helpful to restore degraded landscapes (DARONCO et al., 2012; MEDEIROS et al., 2015; CÂNDIDO et al., 2016). In the AFS, tree component provides organic residue and shadows the soil under the tree canopy, which improves the efficiency in the control of non-native grasses (CORDELL et al., 2004), thereby reducing the need for chemical management (MOORE et al., 2011). In AFS areas, producers can grow a wide variety of food crops, forage, and forest products, increasing income and minimizing poverty in rural areas (LUEDELING et al., 2014; ALTIERI; NICHOLLS, 2017; FAO, 2017). Among all AFS models, the Simple AFS is suitable for farmers interested in getting maximum yield from annual crops in association with forest species, and the Biodiverse AFS is suitable for farmers who aim to diversify agricultural production and restore the environment through the consortium of forest diversification and agricultural species of short, medium and long cycles occupying different strata of plant succession in space or over time (SECRETARIA DO MEIO AMBIENTE, 2018). These two systems influence differently the community of spontaneous plants, depending on the management intensity and shading.

This study was carried out to evaluate the changes that occurred in the phytosociology of the herbaceous stratum as a result of agroecological management in two agroforestry systems (Simple AFS and Biodiverse AFS), compared to homogeneous reforestation of $C$. brasiliense taken as control. The hypothesis is that at least one AFS has favorable attributes for agroecological management of spontaneous vegetation, especially when considering non-native grass control. 


\section{Material and methods}

The experimental area (22053'S; 45⒉'O) is located in Pindamonhangaba (SP), Brazil, average altitude of $544 \mathrm{~m}$, in a river terrace topossequence of soils classified by Santos et al. (2013) as Cambisol (Cambissolo), dystrophic in the upper and middle third, and Planosol (Planossolo), dystrophic, in the lower portion of the terrace. They present similar chemical characteristics: $\mathrm{pH}$ $\left(\mathrm{H}_{2} \mathrm{O}\right)=5.6 ; \mathrm{H}+\mathrm{Al}=3.3 \mathrm{mg} \mathrm{dm}^{-3} ; \mathrm{P}=60.3 \mathrm{mg} \mathrm{dm}^{-3} ; \mathrm{K}=18 \mathrm{mg} \mathrm{dm}^{-3} ; \mathrm{Ca}=1.2 \mathrm{cmol}_{\mathrm{c}} \mathrm{dm}^{-3} ; \mathrm{Mg}=0.8$ $\mathrm{cmol}_{\mathrm{c}} \mathrm{dm}^{-3}$ and organic matter $=22.8 \mathrm{dag} \mathrm{kg}^{-1}$. These soils have uniform appearance and similar hydrological characteristics throughout the series.

Annual rainfall is intense and concentrated in the summer (MATTOS et al., 1998). The local climate is classified as subtropical humid (Cwa) by Köppen and it presents dry winters, with temperatures under $18.0^{\circ} \mathrm{C}$, and hot summers with temperatures that exceed $22.0^{\circ} \mathrm{C}$. The experimental area is surrounded by the Capituba stream and was flooded due to high rainfall in the SpringSummer of 2011 (1307 mm) and 2012 (1497 mm); watercourse interrupted its flow during the extreme drought events that took place in $2013(1158 \mathrm{~mm})$ and in 2014 (619 mm) (TARGA; BATISTA, 2015) (APTA, 2015).

C. brasiliense seedlings were planted at a $3.0 \mathrm{~m} \times 2.0 \mathrm{~m}$ spacing in 2008. In 2011, the agroforestry conversion experiment was installed in a randomized block design with eight replications and $144.0 \mathrm{~m}^{2}$ plots with four rows of six C. brasiliense trees in each line. The treatments were: (T1) monoculture of $C$. brasiliense (control), (T2) Simple AFS and (T3) Biodiverse AFS. In the agroforestry systems, two rows of sweet cassava (Manihot esculenta Crantz) were initially grown alongside the lines of the C. brasiliense; in 2012-2013 and 2013-2014 cycles, arrowroot (Maranta arundinacea L.) was also planted. In the Biodiverse AFS, pigeon pea (Cajanus cajan (L.) Huth) was added alongside the lines of cassava in 2012 as well as green manure, banana shrub and seedlings of 15 native forest species spaced one meter apart. Nine of these native species were pioneer successional: Anadenanthera colubrina (Vell.) Brenan, Bixa orellana L., Citharexylum myrianthum Cham., Croton floribundus Spreng., Erythrina verna Vell., Inga vera Willd., Joannesia princeps Vell., Schinus terebinthifolius Raddi, Schizolobium parahyba (Vell.) Blake; and six of these species were non-pioneer species: Euterpe edulis Mart., Handroanthus impetiginosus (Mart. ex DC.) Mattos, Handroanthus umbellatus (Sond.) Mattos, Magnolia ovata (A.St.-Hil.) Spreng., Pseudobombax grandiflorum (Cav.) A.Robyns e Zanthoxylum rhoifolium Lam. All the native species were recommended for riparian forests recovery (TORRES et al., 1992; LORENZI, 1992; LORENZI, 1998). The cultures received organic and mineral fertilization in the agroforestry systems, and the monoculture got limestone in cover.

The $C$. brasiliense monoculture experimental areas are partially covered by grasses since the biotic components of the ecosystem are less resilient and show tendencies of inertial degradation, according to Cortines and Valcarcel (2009). Agroforestry systems are treatments in which the cultivated species can positively influence the biotic and physical components, modifying the levels of homeostatic balance and defining trends for degradation or restoration (FIGURE 1). 
Figure 1 - Profile of $C$. brasiliense cultivation systems: A - Single crop with grasses alongside the lines; B Simple AFS with arrowroot; C - Biodiverse AFS with arrowroot, banana and tree diversity.
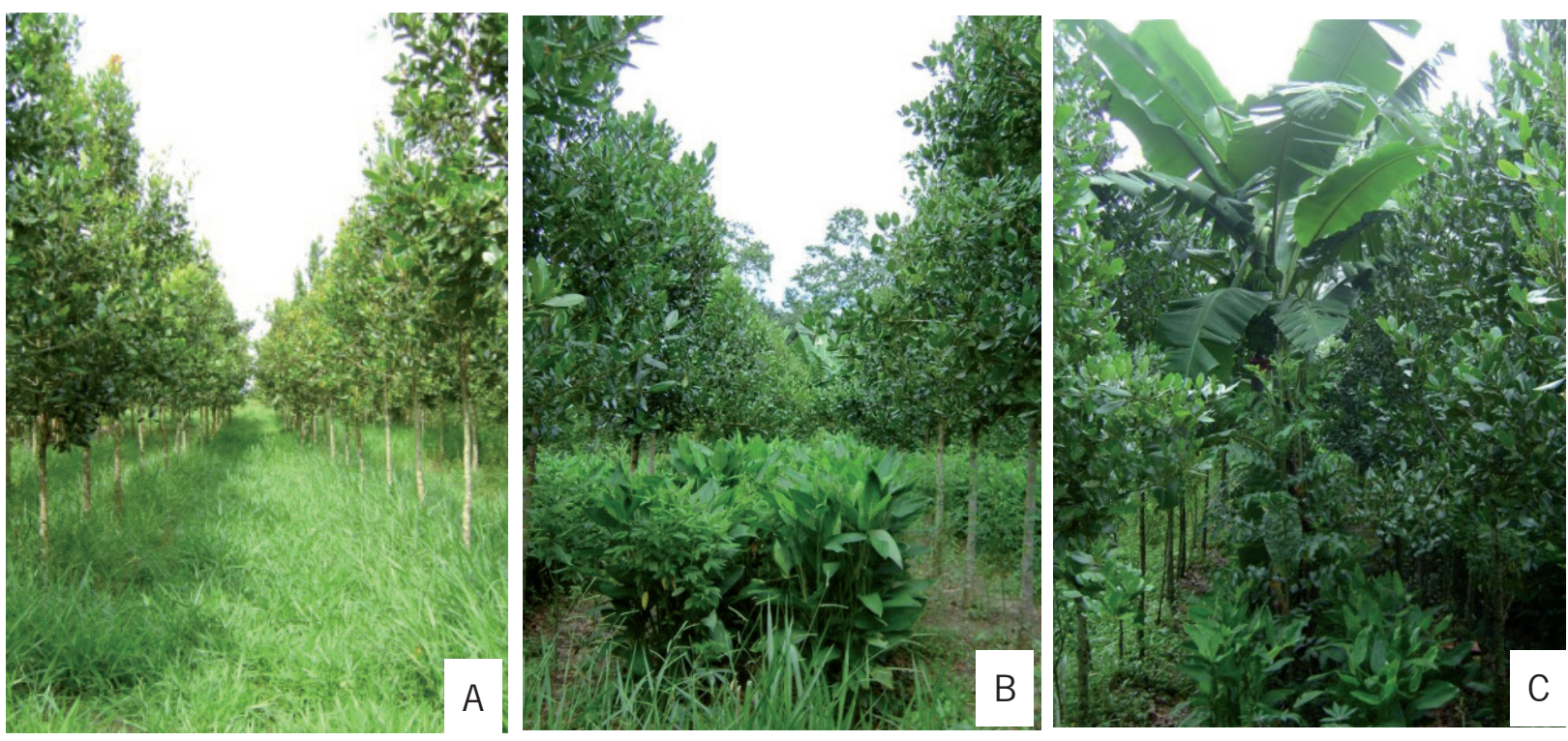

Source: Antonio Devide (2013).

The management of spontaneous vegetation in monoculture consisted of annual mowing and selective weeding using hoes around the trees, for the control of vines; agroforestry systems received manual weeding in the management of consortium crops. Prior to management, a phytosociological survey of the herbaceous layer was carried out on September 19, 2011; September 24, 2012; September 28, 2013; and October 09, 2014. An inventory was made by walking alongside the lines of the $C$. brasiliense and randomly throwing the Braun-Blanquet square inventory $(0,25 \mathrm{~m} \times 0,25 \mathrm{~m})$ eight times in each plot (BRAUN-BLANQUET, 1979; BOLDRINI et al., 2008). All seedlings and herbaceous plants collected in the interior area of the square were identified and compared to literature (LORENZI; MATOS, 2008; LORENZI, 2000). All plants with aerial and underground vegetative parts were considered as individual plants whether they originated from seed propagation or through branches of structure buried in the soil, as an example, grass clumps. Species classification and nomenclature have been updated by APG IV by checking Flora of Brazil 2020 online databases (under construction) and Reflora - Virtual Herbarium 5 .

Absolute frequency (AF\%) and relative frequency (RF\%), relative density (RD\%) and similarity index $(\mathrm{SI} \%)$ were determined as follows:

Absolute Frequency:

$$
A F(\%)=N S s / N S t * 100
$$

at which: NSs: the number of samples in which the species occurred; NSt: the total number of samples.

5 Available in: www.reflora.jbrj.gov.br 
Relative Frequency:

$$
\mathrm{RF}(\%)=\mathrm{AFs} / \mathrm{AFt}^{*} 100
$$

at which: AFs: the absolute frequency of a given species; AFt: the absolute frequency of all species.

Relative density:

$$
\mathrm{RD}(\%)=\ln / \mathrm{Tn} * 100
$$

at which: In: the number of individuals of a given species in the samples; $T n$ : the total number of individuals sampled.

Jaccard Similarity Index:

$$
\mathrm{JSI}=(\mathrm{c} /(\mathrm{a}+\mathrm{b}+\mathrm{c})) * 100
$$

at which: $a$ : the number of species unique to the first community; $b$ : the number of species unique to the second community; $c$ : the number of species common to both communities (MUELLER-DOMBOIS; ELLENBERG, 1974).

\section{Results}

In this study, 41 species, 38 genera, 24 botanical families were identified, and the most abundant were: Asteraceae (nine species), Fabaceae (five species), Poaceae (four species) and Cyperaceae (three species) (TABLE 1). Table 1 lists all species found in the areas, identified with scientific and common names, according to APG IV. The greatest richness of species of herbaceous plants was found in Simple AFS (35 species) followed by Biodiverse AFS (34 species), which were greater than monoculture (25 species); in general, eudicotyledons class prevailed.

\begin{tabular}{|c|c|c|c|c|c|c|}
\hline Family & Scientific name & Popular name & Class $^{1}$ & $\begin{array}{l}\text { Mono } \\
\text { culture }\end{array}$ & $\begin{array}{l}\text { Simple } \\
\text { AFS }\end{array}$ & $\begin{array}{l}\text { Biodiverse } \\
\text { AFS }\end{array}$ \\
\hline ACANTHACEAE & $\begin{array}{l}\text { Thunbergia alata } \\
\text { Bojer ex Sims }\end{array}$ & cipó-africano & $E$ & $x$ & - & $x$ \\
\hline APIACEAE & Bidens pilosa L. & picão & $\mathrm{E}$ & $x$ & $x$ & $x$ \\
\hline ASTERACEAE & Ageratum conyzoides L. & $\begin{array}{l}\text { erva-de-são- } \\
\text { joão }\end{array}$ & $E$ & $x$ & $x$ & $x$ \\
\hline ASTERACEAE & $\begin{array}{l}\text { Conyza bonariensis } \\
\text { (L.) Cronquist }\end{array}$ & buva & $E$ & $x$ & $x$ & $x$ \\
\hline ASTERACEAE & $\begin{array}{l}\text { Emilia sonchifolia } \\
\text { (L.) DC. ex Wight }\end{array}$ & serralinha & $E$ & $x$ & $x$ & $x$ \\
\hline ASTERACEAE & $\begin{array}{l}\text { Foeniculum vulgare } \\
\text { Mill }\end{array}$ & funcho & $\mathrm{E}$ & - & $x$ & - \\
\hline ASTERACEAE & $\begin{array}{l}\text { Galinsoga parviflora } \\
\text { Cav. }\end{array}$ & botão de ouro & $\mathrm{E}$ & - & $x$ & - \\
\hline ASTERACEAE & $\begin{array}{l}\text { Solidago chilensis } \\
\text { Meyen }\end{array}$ & $\begin{array}{l}\text { arnica } \\
\text { brasileira }\end{array}$ & $\mathrm{E}$ & - & $x$ & - \\
\hline ASTERACEAE & Sonchus oleraceus L. & serralha & $E$ & - & $x$ & $x$ \\
\hline
\end{tabular}

Table 1 - Botanical families, scientific name, popular and species richness of the herbaceous layer in $C$. brasiliense planting in river terrace, Pindamonhangaba (SP), Brazil 


\begin{tabular}{|c|c|c|c|c|c|c|}
\hline Family & Scientific name & Popular name & Class $^{1}$ & $\begin{array}{l}\text { Mono } \\
\text { culture }\end{array}$ & $\begin{array}{l}\text { Simple } \\
\text { AFS }\end{array}$ & $\begin{array}{c}\text { Biodiverse } \\
\text { AFS }\end{array}$ \\
\hline ASTERACEAE & $\begin{array}{l}\text { Synedrellopsis } \\
\text { grisebachii Hieron. \& } \\
\text { Kuntze }\end{array}$ & agriãozinho & $E$ & $x$ & $x$ & - \\
\hline ASTERACEAE & $\begin{array}{l}\text { Taraxacum officinale } \\
\text { Web }\end{array}$ & dente-de-leão & $E$ & - & $x$ & $x$ \\
\hline BRASSICACEAE & $\begin{array}{l}\text { Coronopus didymus } \\
\text { (L.) Sm. }\end{array}$ & mastruz & $E$ & $x$ & - & $x$ \\
\hline CALOPHYLLACEAE & $\begin{array}{l}\text { Calophyllum } \\
\text { brasiliense Cambess. }\end{array}$ & guanandi & $E$ & - & $x$ & $x$ \\
\hline COMMELINACEAE & $\begin{array}{l}\text { Commelina } \\
\text { benghalensis L. }\end{array}$ & trapoeraba & $E$ & $x$ & $x$ & $x$ \\
\hline CONVOLVULACEAE & Ipomea purpurea L. & corda-de-viola & $E$ & $x$ & $x$ & $x$ \\
\hline CUCURBITACEAE & Momordica charantia L. & $\begin{array}{l}\text { melão-de-são- } \\
\text { caetano }\end{array}$ & $E$ & $x$ & $x$ & $x$ \\
\hline CYPERACEAE & Cyperus rotundus L & tiririca & $M$ & $x$ & $x$ & $x$ \\
\hline CYPERACEAE & Eleocharis R.Br. & capim fino & M & $x$ & $x$ & $x$ \\
\hline CYPERACEAE & $\begin{array}{l}\text { Rhynchospora alba } \\
\text { (L.) Vahl }\end{array}$ & cebolinha & M & $x$ & $x$ & $x$ \\
\hline FABACEAE & $\begin{array}{l}\text { Arachis pintoi Krapov. } \\
\text { \& W.C.Greg. }\end{array}$ & $\begin{array}{l}\text { amendoim } \\
\text { forrageiro }\end{array}$ & $E$ & - & $x$ & $x$ \\
\hline FABACEAE & $\begin{array}{l}\text { Centrosema plumieri } \\
\text { (Turpin ex Pers.) } \\
\text { Benth. }\end{array}$ & cipó bravo & E & $x$ & $x$ & $x$ \\
\hline FABACEAE & $\begin{array}{l}\text { Centrosema } \\
\text { virginianum (L.) } \\
\text { Benth. }\end{array}$ & feijão bravo & $E$ & $x$ & $x$ & $x$ \\
\hline FABACEAE & Mimosa pudica L. & dormideira & E & - & $x$ & $x$ \\
\hline FABACEAE & $\begin{array}{l}\text { Senna obtusifolia (L.) } \\
\text { H.S.Irwin \& Barneby }\end{array}$ & fedegoso & $E$ & $x$ & - & $x$ \\
\hline HYPOXIDACEAE & Hypoxis decumbens L. & $\begin{array}{l}\text { tiririca-de-flor- } \\
\text { amarela }\end{array}$ & M & - & $x$ & - \\
\hline LYTHRACEAE & $\begin{array}{l}\text { Cuphea } \\
\text { carthagenensis (Jacq.) } \\
\text { J.F. Macbr. }\end{array}$ & sete sangria & E & - & $x$ & - \\
\hline MALVACEAE & $\begin{array}{l}\text { Malvastrum } \\
\text { coromandelianum } \\
\text { Garcke }\end{array}$ & guanxuma & E & $x$ & $x$ & $x$ \\
\hline MARANTACEAE & $\begin{array}{l}\text { Maranta arundinacea } \\
\text { L. }\end{array}$ & araruta & M & $x$ & $x$ & $x$ \\
\hline ONAGRACEAE & $\begin{array}{l}\text { Ludwigia longifolia } \\
\text { (DC.) H.Hara. }\end{array}$ & cruz-de-malta & E & $x$ & $x$ & $x$ \\
\hline ORCHIDACEAE & $\begin{array}{l}\text { Oceoclades maculata } \\
\text { (Lindley) Lindley }\end{array}$ & orquídea & M & $x$ & $x$ & $x$ \\
\hline OXALIDACEAE & Oxalis latifolia Kunth & trevo & $E$ & - & $x$ & $x$ \\
\hline PHYLLANTHACEA & $\begin{array}{l}\text { Phyllanthus tenellus } \\
\text { Roxb. }\end{array}$ & quebra-pedra & $E$ & $x$ & $x$ & $x$ \\
\hline
\end{tabular}




\begin{tabular}{|c|c|c|c|c|c|c|}
\hline Family & Scientific name & Popular name & Class $^{1}$ & $\begin{array}{l}\text { Mono } \\
\text { culture }\end{array}$ & $\begin{array}{l}\text { Simple } \\
\text { AFS }\end{array}$ & $\begin{array}{c}\text { Biodiverse } \\
\text { AFS }\end{array}$ \\
\hline POACEAE & Cenchrus echinatus L. & $\begin{array}{l}\text { capim } \\
\text { carrapicho }\end{array}$ & M & - & $x$ & $x$ \\
\hline POACEAE & $\begin{array}{l}\text { Cynodon dactylon (L.) } \\
\text { Pers. }\end{array}$ & grama seda & M & $x$ & $x$ & $x$ \\
\hline POACEAE & $\begin{array}{l}\text { Eleusine indica (L.) } \\
\text { Gaertn. }\end{array}$ & $\begin{array}{l}\text { capim-pé-de- } \\
\text { galinha }\end{array}$ & M & $x$ & $x$ & $x$ \\
\hline POACEAE & $\begin{array}{l}\text { Urochloa decumbens } \\
\text { (Stapf) R.D.Webster }\end{array}$ & brachiaria & M & $x$ & $x$ & $x$ \\
\hline PORTULACACEAE & Portulaca oleracea L. & beldroega & $E$ & - & - & $x$ \\
\hline SOLANACEAE & $\begin{array}{l}\text { Solanum americanum } \\
\text { Mill. }\end{array}$ & maria-pretinha & E & $x$ & $x$ & $x$ \\
\hline SOLANACEAE & $\begin{array}{l}\text { Solanum } \\
\text { sisymbriifolium Lam. }\end{array}$ & $\begin{array}{l}\text { joá-mata- } \\
\text { cavalo }\end{array}$ & E & $x$ & - & $x$ \\
\hline TALINACEAE & $\begin{array}{l}\text { Talinum paniculatum } \\
\text { (Jacq.) Gaertn. }\end{array}$ & major-gomes & $E$ & - & $x$ & $x$ \\
\hline Total & & & & 26 & 35 & 34 \\
\hline
\end{tabular}

${ }^{1} \mathrm{E}$ - eudicotyledons; $\mathrm{M}$ - Monocotyledons

Source: Elaborated by the authors (2014).

Table 2 shows the most abundant species and the largest number of individuals after three years of management. In the monoculture, $U$. decumbens, $C$. rotundus and $C$. benghalensis predominate; in Simple AFS, C. benghalensis, B. pilosa, M. arundinacea predominate, and in Biodiverse AFS, C. brasiliense, $M$. arundinacea and $C$. benghalensis predominate.

Table 2 - Absolute frequency (AF), relative frequency (RF), relative density (RD) of 15 species of herbaceous strata abundant on a river terrace, in monoculture (T1), Simple AFS (T2) and Biodiverse AFS (T3).

\begin{tabular}{lccccccccc}
\hline \multirow{2}{*}{ Species } & \multicolumn{3}{c}{ AF } & & \multicolumn{3}{c}{ RF } & \multicolumn{3}{c}{ RD } \\
\cline { 2 - 10 } & T1 & T2 & T3 & T1 & T2 & T3 & T1 & T2 & T3 \\
\hline U. decumbens & 25 & 2 & 0 & 62 & 4 & 0 & 64 & 2 & 0 \\
C. rotundus & 5 & 4 & 0 & 13 & 7 & 0 & 14 & 5 & 0 \\
C. benghalensis & 3 & 15 & 3 & 8 & 25 & 19 & 6 & 36 & 22 \\
P. tenellus & 3 & 5 & 1 & 6 & 8 & 3 & 6 & 8 & 2 \\
R. alba & 2 & 2 & 0 & 4 & 3 & 0 & 3 & 2 & 0 \\
C. virginianum & 1 & 1 & 0 & 3 & 1 & 0 & 2 & 1 & 0 \\
O. latifolia & 1 & 2 & 0 & 1 & 4 & 0 & 2 & 2 & 0 \\
Amaranthus sp. & 1 & 2 & 0 & 1 & 3 & 0 & 1 & 2 & 0 \\
C. bonariensis & 1 & 5 & 0 & 1 & 8 & 0 & 2 & 14 & 0 \\
B. pilosa & 0 & 7 & 0 & 0 & 12 & 0 & 0 & 12 & 0 \\
S. oleraceae & 0 & 2 & 0 & 0 & 3 & 0 & 0 & 2 & 0 \\
T. alata & 0 & 2 & 0 & 0 & 4 & 0 & 0 & 2 & 0 \\
T. paniculatum & 0 & 2 & 0 & 0 & 4 & 0 & 0 & 3 & 0 \\
M. arundinacea & 0 & 6 & 5 & 0 & 10 & 31 & 0 & 7 & 26 \\
C. brasiliense & 0 & 1 & 6 & 0 & 2 & 37 & 0 & 1 & 41 \\
\hline
\end{tabular}

Source: Elaborated by the authors (2014). 
After three years of management, the phytosociological similarity of the Biodiverse AFS herbaceous plant community diverged from other cultivation systems (TABLE 3).

Table 3 - Jaccard Similarity Index (SI\%) of spontaneous plants in C. brasiliense monoculture (T1), Simple AFS (T2) and Biodiverse AFS (T3) on a river terrace

\begin{tabular}{ccccc}
\hline Treatments & $\mathbf{2 0 1 1}$ & $\mathbf{2 0 1 2}$ & $\mathbf{2 0 1 3}$ & $\mathbf{2 0 1 4}$ \\
\hline T1/T2 & 54 & 58 & 60 & 50 \\
T1/T3 & 80 & 60 & 69 & 14 \\
T2/T3 & 52 & 71 & 67 & 18 \\
Average & 62 & 63 & 65 & 27 \\
\hline
\end{tabular}

Source: Elaborated by the authors (2014).

\section{Discussion}

In the present research, forage grasses were the most abundant species in monoculture, showing that mowing and weeding around the $C$. brasiliense trees were inefficient practices to control Urochloa. This species is one of the most important problem for forest natural regeneration once it competes for nutrients and water, preventing the establishment of native species (VIEIRA et al., 1994; NEPSTAD et al., 1996; SOUZA; BATISTA, 2004; CORTINES; VALCARCEL, 2009). In another study, about a silvopastoral system installation with the pequizeiro (Caryocar brasiliense Cambess.), the grasses Panicum L. and Urochloa P.Beauv. presented a high vegetative development and productivity of dry matter, causing the suppression of styling (Stylosanthes capitata Vogel and Stylosanthes macrocephala M. B. Ferreira \& Sousa Costa) in the consortium (FAVARE et al., 2018). Grasses are C4 plants adapted to full sun that occupy open areas, which can reduce the diversity of herbaceous (RIBEIRO et al., 2005) and woody species from natural regeneration and they can also increase the vulnerability of those areas to fire (CABIN et al., 2002; CORTINES; VALCARCEL, 2009; MOORE et al., 2011; FLORY et al., 2015; MANTOANI; TOREZAN, 2016). Areas infested by grasses have less resilient biotic components of the ecosystem and tend to inertial degradation, by ruderal herbaceous species, with intense cycles of plant growth and senescence, producing a highly flammable dry biomass in hot and dry periods, which inhibits the growth of woody species, whereas in the forest environment there is a natural tendency towards restoration (CORDELL et al., 2004; CORTINES; VALCARCEL, 2009; MOORE et al., 2011). Infestation of non-native grasses can cause damage to crops and forest species, with decreases in productivity, either by direct competition for natural resources or for allelopathic compounds released (SOUSA et al., 2003).

However, many grasses are planted in alleys in AFS aiming to provide phytomass and accelerate the restoration of degraded soils (MICCOLIS et al., 2016). Management is carried out by frequent cut, according to César et al. (2013). Depending on the intensity of management and the location of phytomass in the surroundings or in the cultivation lines of commercial species, grasses form a layer of organic matter that recycles nutrients and maintains soil moisture (MICCOLIS et al., 2016).

In the present research, in agroforestry management, the number of dicotyledonous plants has increased while the number of monocotyledonous plants had decreased due to shading conditions. The Biodiverse AFS with higher density of plants and higher species diversity had greater shading, which resulted in efficient grass control, compared to the Simple AFS. This corroborates the results 
of other authors who reported that shading is the best mechanism for invasive non-native grasses control (CORTINES; VALCARCEL, 2009), as verified in the ecological restoration of riparian forests (MOORE et al., 2011), and also in dry forests (CODELL et al., 2004) and in AFS with suppression of guinea grass (Megathyrsus maximus (Jacq.) B.K. Simon \& S.W.L. Jacobs) by canopy cover of native tree vegetation (MANTOANI; TOREZAN, 2016).

In all commercial reforestations (PYWELL et al., 2010), regenerative reforestation (MOORE et al., 2011) and AFS, the tree component, improves efficiency in controlling non-native grasses through shading. The input of organic matter from the tree component improves soil fertility, controls erosion, reduces nutrient leaching (WEZEL et al., 2014), increases soil water availability and resilience to extreme drought conditions (BASCHE; EDELSON, 2017), which occurs frequently in tropical regions (TARGA; BATISTA, 2015).

In tropical agrosystems, dominant invasive plant communities are made up of native and cosmopolitan species and agricultural practices such as soil and crop management, significantly, influence the floristic composition and the size of invasive plant communities (SOUSA et al. , 2003) in addition to soil attributes (MENEZES et al., 2008).

The Jaccard similarity index, applied on the species of all treatments, can indicate trends for spontaneous regeneration (MAGURRAN, 1988; CORTINES; VALCARCEL, 2009) and demonstrates the sustainability of restoration treatments. While the density of Urochloa remained high in monoculture, in AFS, the spaces alongside the lines of $C$. brasiliense were occupied by crop consortium. The areas of monoculture and Simple AFS were more similar in species composition, varying from $54.0 \%$ to $60.0 \%$ over the years (TABLE 3). Cortines and Valcarcel (2009) found the terrestrial orchid 0 . maculata in forest areas. In the present study, the occurrence of this specie in the Biodiverse AFS characterizes an attribute of spontaneous regeneration of mature forest (CORTINES; VALCARCEL, 2009) with favorable conditions for the recruitment of other species in the advanced stage of natural regeneration. With species similarity between $14.0 \%$ and $18.0 \%$, Biodiverse AFS was the system that differed from the others. By intercepting the light energy in the different strata and adding organic matter to the soil, Biodiverse AFS provided the biggest changes in the environment, favorable to the recruitment of shade-tolerant species, such as $C$. benghalensis and $M$. arundinacea.

The introduction of $M$. arundinacea as a cultivated plant turned this species into a bioindicator of environmental resilience in AFS. Due to its rusticity and natural occurrence in the forests of Rio de Janeiro, M. arundinacea tolerates shading (MONTEIRO; PERESSIN, 2002; FELTRAN; PERESSIN, 2014), produces rhizomes and abundant aerial biomass (ODEKU, 2013; SWADIJA et al. 2013; SHINTU et al., 2015; ROHANDI et al., 2017) enabling its perennial establishment under favorable conditions. Bianchi et al. (2016) consider geophyte plants that use carbohydrates stored in rhizomes to regenerate as the most adapted to water stress. Grown in the $C$. brasiliense reforestation understorey, M. arundincea was an important native species for ecological restoration work, especially in riparian areas susceptible to flooding, due to its ability to regenerate itself from parts of rhizomes buried in the soil, even in severe water restriction conditions, $M$. arundinacea started to occupy the sites previously colonized by Urochloa in the shaded environment of Biodiverse AFS. As a native spontaneous plant of high mycorrhizal activity, $M$. arundinacea can benefit the $C$. brasiliense in addition to rhizomes production in a low environmental impact exploitation model by dispensing soil preparation and turnover for replanting in the AFS.

The origin of the $C$. brasiliense seedlings in the Biodiverse AFS also indicates that there is no barrier to tree colonization; partly due to the presence of litter inherent to agroforestry management 
and the presence of natural perches for dispersing bats, which were positioned on the underside face of banana leaves. In addition, grasses form a dense vegetation cover that prevents seeds from reaching the soil (WHELAN et al., 1991; AIDE et al., 1995), or harm its viability due to its high competition (CORTINES; VALCARCEL, 2009), which are justifications for low natural resilience in the areas of monoculture and Simple AFS.

Among the beneficial effects of AFS, in addition to shading, it is worth mentioning the improvement in soil fertility, especially due to the expressive accumulation of organic residues from banana shrubs, which can reach $55.0 \mathrm{t} \mathrm{ha}^{-1}$ (DEVIDE et al., 2019). The improvement in soil fertility makes the plants of interest more competitive and able to maintain growth and overlap spontaneous vegetation, even in restricted drought conditions. Sousa et al. (2003) also attributed the reduction of monocots number in AFS with cupuaçuzeiro tree (Theobroma grandiflorum (Willd. ex Spreng.) Schum.), banana shrub (Musa sp), pupunha palm (Bactris gasipaes Kunth) and ingá tree (Inga edulis Mart.) in different soil management systems after adding fertilizers and organic matter.

In the present study, the agroecological management of spontaneous vegetation in the AFS strengthens the conservation of soil and water resources. Chemical grass control is not desirable in this environment due to the topossequence slope, soil permeability and proximity to the watercourse. Cultivation between the lines of reforestation is an efficient technique for controlling non-native inva-

sive grasses and can generate extra income from food production (CÉSAR et al., 2013; CÂNDIDO et al., 2016). Promoting multi-purpose forestry is a sustainable alternative to generate income, strengthen food production, and increase soil, water volume, and biodiversity conservation on rural properties (MONTAGNINI, 2012; ARÉVALO-GARDINI et al., 2015; DEVIDE et al., 2014). In this context, agroforestry cultivation of food species with native trees can control undesirable spontaneous plants (OLIVEIRA et al., 2016; CÉSAR et al., 2013) and favors environmental restoration.

\section{Conclusions}

Biodiverse AFS reduces the density of spontaneous plants, due to the shading of the species that occupy different strata alongside the lines of $C$. brasiliense.

The similarity of spontaneous vegetation diverged after three years of agroforestry management, with the selection of eudicotyledonous species in the areas of AFS and predominance of Urochloa in monoculture.

\section{Acknowledgments}

To the Postgraduate Course in Phytotechnics, Area of Concentration in Agroecology, at the Federal Rural University of Rio de Janeiro (UFRRJ) and the Agricultural Research Support Foundation (FUNDAG), for supporting this research within the scope of the first author's PhD.

\section{Fitossociologia herbácea comparada em sistemas agroflorestais e monocultivo de guanandi em terraço fluvial}

\section{Resumo}

Gramíneas forrageiras invasivas, principalmente do gênero Urochloa, impactam os reflorestamentos no mundo todo. 0 objetivo deste estudo foi avaliar alterações na fitossociologia do estrato her- 
báceo, definido como a camada de ervas, subarbustos, arbustos e trepadeiras, em função do manejo de dois sistemas agroflorestais (SAF Simples e SAF Biodiverso) na conversão de reflorestamento de guanandi (Calophyllum brasiliense), comparado ao monocultivo (testemunha). 0 experimento foi conduzido entre os anos de 2011-2014 em delineamento em blocos ao acaso com oito repetições e parcelas de $144,0 \mathrm{~m}^{2}$. Nos sistemas agroflorestais foram cultivadas culturas alimentares de mandioca (Manihot esculenta) e rotação com araruta (Maranta arundinacea) nas entrelinhas do guanandi, acrescidas de guandu (Cajanus cajan), bananeira (Musa sp.), palmeira juçara (Euterpe edulis) e 14 espécies arbóreas nativas no SAF Biodiverso. Ao todo foram identificadas 41 espécies no estrato herbáceo, 38 gêneros e 24 famílias botânicas, sendo Asteraceae, Poaceae e Cyperaceae as mais abundantes. A similaridade entre as áreas divergiu após três anos de manejo, com o predomínio de Commelina benghalensis e M. arundinacea nos SAF e Urochloa decumbens no monocultivo, principalmente, em função do gradiente de sombra estabelecido entre os três sistemas.

Palavras-chave: Reflorestamento ecológico; Biodiversidade; Plantas espontâneas.

\section{References}

AgÊNCIA PAUlista DE TECNOLOGIA dOS AGRONEGÓCIOS (APTA). Dados climáticos do Posto Meteorológico do Polo Regional do Vale do Paraíba, Pindamonhangaba - SP, 2015.

AGRAWAL, A.; PANDEY, R. S.; SHARMA, B. Water Pollution with Special Reference to Pesticide Contamination in India. J. Water Resource and Protection, v. 2, p. 432-448, 2010. Disponível em: <http://doi:10.4236/jwarp.2010.25050>. Acesso em: 05 abr. 2019.

AIDE, T. M.; CAVELIER, J. Barriers to lowland forest restoration in the Sierra Nevada de Santa Marta, Colombia. Restoration Ecology, v. 2, n. 4, p. 219-229, 1994. Disponível em: <http://doi. org/10.1111/j.1526-100X.1994.tb00054.x>. Acesso em: 02 fev. 2019.

ALTIERI, M. A.; NICHOLLS, C. I. The adaptation and mitigation potential of traditional agriculture in a changing climate. Climatic Change, v. 140, n. 1, p. 33-45, 2017. Disponível em: <http://article/10.1007/s10584-013-0909-y>. Acesso em: 02 abr. 2019.

ARÉVALO-GARDINI, E.; CANTO, M.; ALEGRE, J.; LOLI, O.; JULCA, A.; BALIGAR, V. Changes in Soil Physical and Chemical Properties in Long Term Improved Natural and Traditional Agroforestry Management Systems of Cacao Genotypes in Peruvian Amazon. PLoS ONE, v. 10, n. 7, e0132147, 2015. Disponível em: <https://doi.org/10.1371/journal.pone.0132147>. Acesso em: 08 mar. 2019.

BASCHE, A. D.; EDELSON, O. F. Improving water resilience with more perennially based agriculture. Agroecology and Sustainable Food Systems, v. 41, n. 7, p. 799-824, 2017. Disponível em: <https://doi/full/10.1080/21683565.2017.1330795>. Acesso em: 08 mar. 2019.

BIANCHI, L.; GERMINO, G. H.; SILVA, M. A. Adaptação das plantas ao déficit hídrico. Acta Iguazu, v. 5, n. 4, p. 15-32, 2016. Disponível em: <http://index.php/actaiguazu/article/view/16006>. Acesso em: 02 fev. 2019. 
BOLDRINI, I. I.; TREVISAN, R.; SCHNEIDER, A. A. Estudo florístico e fitossociológico de uma área às margens da Lagoa do Armazém, Osório, Rio Grande do Sul, Brasil. Revista Brasileira de Biociências, v. 6, n. 4, p. 355-367, out./dez. 2008. Disponível em: <http://www.ufrgs.br/seerbio/ojs/index.php/ rbb/article/viewFile/1117/835>. Acesso em: 02 abr. 2019.

BRAUN-BLANQUET J. Fitosociologia: bases para el estúdio de las comunidades vegetales. 3. ed., Madrid: Aum, 1979.

BRENES, A. R.; MONTAGNINI, F. Growth, productivity, aboveground biomass, and carbon sequestration of pure and mixed native tree plantations in the Caribbean lowlands of Costa Rica. Forest Ecology and Management; v. 232, n. 1/3, p. 168-178, 2006. Disponível em: <http://doi:10.1016/j. foreco.2006.05.067>. Acesso em: 08 dez. 2017.

BRITO, N. M.; AMARANTE JUNIOR, O. P. de; ABAKERLI, R.; SANTOS, T. C. R. dos; RIBEIRO, M. L. Risco de contaminação de águas por pesticidas aplicados em plantações de eucaliptos e coqueiros: análise preliminar. Pesticidas: Revista de Ecotoxicologia e Meio Ambiente, v. 11, p. 93-104, jan./ dez. 2001. Disponível em: <http://doi:10.5380/pes.v11i0.3138>. Acesso em: 04 abr. 2019.

CABIN, R. J.; WELLER, S. G.; LORENCE, D. H.; CORDELL, S.; HADWAY, L. J.; MONTGOMERY, R.; GOO, D.; URAKAMI, A. Efects of light, alien grass, and native species additionson Hawaiian dry forest restoration. Ecological Applications, v. 12, n. 6, 2002, p. 1595-1610. Disponível em: <https://doi. org/10.1890/1051-0761(2002)012[1595:EOLAGA]2.0.CO;2>. Acesso em: 04 mar. 2017.

CÂNDIDO, V. A.; PINTO, L. V. A.; BOGARIMP, P. C.; ROSAS, D. da; SILVA, R. M.; BARBOSA, J. M. N. Sistema agroflorestal para recomposição de reserva legal em propriedades de agricultores familiares. Revista Agrogeoambiental, v. 8, n. 2, p. 65-72, Jun. 2016. Disponível em: <DOI: http://dx.doi. org/10.18406/2316-1817v8n22016821 >. Acesso em: 08 abr. 2019.

CARVALHO, P. E. R. Guanandi. Colombo: Embrapa Florestas, 2003. 14p. (Circular Técnica n. 78).

CÉSAR, R. G.; BRANCALION, P. H. S.; RODRIGUES, R. R. Does crotalaria (Crotalaria breviflora) or pumpkin (Cucurbita moschata) inter row cultivation in restoration plantings control invasive grasses? Scientia Agricola, v. 70, p. 268 - 273, 2013. Disponível em: <http://dx.doi.org/10.1590/S010390162013000400008>. Acesso em: 06 fev. 2019.

CORDELL, S.; SANDQUIST, D. R.; LITTON, C.; CABIN, R. J.; THAXTON, J.; HADWAY, L.; CASTILLO, J. M.; BISHAW, D. An invasive grass has significant impacts on tropical dry forest ecosystems in Hawaii. 16th Int'l Conference, Society for Ecological Restoration, August 24-26, 2004, Anais..., Victoria, Canada.

CORTINES, E.; VALCARCEL, R. Influence of pioneer-species combinations on restoration of disturbed ecosystems in the Atlantic Forest, Rio de Janeiro, Brazil. Revista Árvore, v. 33, n. 5, p. 927-936, 2009. Disponível em: <http://dx.doi.org/10.1590/S0100-67622009000500015>. Acesso em: 03 fev. 2018. 
DARONCO, C.; MELO, A. C. G.; MACHADO, J. A. R. Consórcio de espécies nativas da Floresta Estacional Semidecidual com mandioca (Manihot esculenta Crantz) para restauração de mata ciliar. Revista Árvore, v. 36, n. 2, p. 291-299, 2012. Disponível em: <http://dx.doi.org/10.1590/S0100$67622012000200010>$. Acesso em: 12 jan. 2018.

DEVIDE, A. C. P.; CASTRO, C. M. de; RIBEIRO, R. L. D. Cultivo agroflorestal de bananeira com guanandi resiliente às alterações climáticas. Revista Pesquisa \& Tecnologia, v. 16, n. 1, p. 1-9, 2019. Disponível em: < https://www.researchgate.net/publication/333149196_CULTIVO_AGROFLORESTAL_DE_BANANEIRA_COM_GUANANDI_RESILIENTE_AS_ALTERACOES_CLIMATICAS >. Acesso em: 11 jul. 2019.

DEVIDE, A. C. P.; CASTRO, C. M. de; RIBEIRO, R. L. D.; ABBOUD, A. C. S.; PEREIRA, M. G.; RUMJANEK, N. G. História Ambiental do Vale do Paraíba Paulista, Brasil. Revista Biociências, v. 20, n. 1, p. 12-29, 2014. Disponível em: <http://periodicos.unitau.br/ojs/index.php/biociencias/article/ view/1867>. Acesso em: 04 mar. 2019.

DURIGAN, G.; NOGUEIRA, J. C. B. Recomposição de matas ciliares. São Paulo: Instituto Florestal, 1990. 14 p.

FAVARE, H. G.; TSUKAMOTO, A. A.; COSTA, R. B.; PASA, M. C.; FAVARE, L. G. Desempenho de forrageiras em sistema silvipastoril com Caryocar brasiliense Camb. Cultura Agronômica, v. 27, n. 3, p. 340-353, 2018. Disponível em: <http://ojs.unesp.br/index.php/rculturaagronomica/article/ view/2572/2041>. Acesso em: 04 fev. 2018.

FElTRAN, J. C.; PERESSIN, V. A. Araruta. In: AGUIAR, A. T. E.; GONÇAlVES, C.; PATERNIANI, M. E. A. G. Z.; TUCCI, M. L. S.; CASTRO, C. E. F. de. Instruções agrícolas para as principais culturas econômicas. Campinas: Instituto Agronômico, v. 6, 2014, p. 36-38. (Boletim 200). Disponível em: <http:// www.iac.sp.gov.br/publicacoes/porassunto/pdf/boletim200_iac.pdf>. Acesso em: 13 mar. 2018.

FLORA DO BRASIL (2020 em construção) Flora do Brasil. Jardim Botânico do Rio de Janeiro. Disponível em <http://floradobrasil.jbrj.gov.br/>. Acesso em: 10 jul. 2019.

FLORY, S. L.; CLAY, K.; EMERY, S. M.; ROBB, J. R.; WINTERS, B. Fire and non-native grass invasion interact to suppress tree regeneration in temperate deciduous forests. Journal of Applied Ecology, $v$. 52, p. 992-1000, 2015. Disponível em: <https://doi.org/10.1111/1365-2664.12437>. Acesso em: 12 fev. 2019.

FOOD AND AGRICULTURE ORGANIZATION (FAO). Agroforestry for landscape restoration: Exploring the potential of agroforestry to enhance the sustainability and resilience of degraded landscapes. Roma: FAO, 2017. 28p. Disponível em: <http://www.fao.org/3/b-i7374e.pdf>. Acesso em: 08 fev. 2017.

GARCÍA-ORTH, X.; MARTÍNEZ-RAMOS, M. Isolated trees and grass removal improve performance of transplanted Trema micrantha (L.) Blume (Ulmaceae) saplings in tropical pastures. Restoration Ecology, v. 19, p. 24 - 34, 2011. Disponível em: <https://doi.org/10.1111/j.1526-100X.2009.00536. x>. Acesso em: 12 abr. 2018. 
KRONKA, F. J. N.; NALON, M. A.; MATSUKUMA, C. K.; KANASHIRO, M. M.; SHIN-IKE, M. S.; PAVÃO, M.; DURIGAN, G.; LIMA, L. P. R.; GUILLAUMON, J. R.; BAITELLO, J. B.; BORGO, S. C.; MANETTI, L. A.; BARRADAS, A. M. F.; FUKUDA, J. C.; SHIDA, C. N.; BARBOSA, O.; SOARES, A. P.; JOLY, C. A.; COUTO, H. T. Z. Inventário florestal da vegetação natural do estado de São Paulo. São Paulo: Secretaria do Meio Ambiente; Instituto Florestal; Imprensa Oficial, 2005, 200 p. Disponível em: <http://iflorestal.sp.gov.br/2005/03/01/inventario-florestal-da-vegetacao-natural-do-estado-de-sao-paulo/>. Acesso em: 08 abr. 2018.

LONDE, V.; SILVA, J. C. Characterization of Poaceae (grass) species as indicators of the level of degradation in a stretch of riparian forest in Matutina, Brazil. Acta Botânica Brasílica, v. 28, n. 1, p. 102-108, 2014. Disponível em: <http://dx.doi.org/10.1590/S0102-33062014000100010>.

LORENZI, H. Plantas daninhas do Brasil: terrestres, aquáticas, parasitas, tóxicas e medicinais. 3. ed. Nova Odessa: Instituto Plantarum, 2000. 608 p.

LORENZI, H.; MATOS, F.J.A. Plantas medicinais no Brasil: nativas e exóticas. 2. ed. Nova Odessa: Instituto Plantarum, 2008. 544p.

LORENZI, H. Árvores brasileiras: manual de identificação e cultivo de plantas arbóreas nativas do Brasil. Nova Odessa: Plantarum, 1992. 368 p.

LORENZI. H. Árvores brasileiras: manual de identificação e cultivo de plantas arbóreas do Brasil. v. 2. Nova Odessa: Plantarum, 1998. 350 p.

LUEDELING, E.; ROELAND, K.; HUTH, N. I.; KOENING, K. Agroforestry systems in a changing climate - challenges in projecting future performance. Current Opinion in Environmental Sustainability, v. 6, p. 1-7, 2014. Acesso em: <http://doi.org/10.1016/j.cosust.2013.07.013>. Acesso em: 12 abr. 2018.

MANTOANI, M. C.; TOREZAN, J. M. D. Regeneration response of Brazilian Atlantic Forest woody species to four years of Megathyrsus maximus removal. Forest Ecology and Management, v. 359, p. 141-146, 2016. Disponível em: <http://dx.doi.org/10.1016/j.foreco.2015.10.004>. Acesso em: 08 maio 2018.

MEDEIROS, R. A.; PAIVA, H. N.; LEITE, H. G.; OLIVEIRA NETO, S. N.; VENDRÚSCOLO, D. G. S.; SILVA, F. T. Análise silvicultural e econômica de plantas clonais e seminais de Tectona grandis L.f. em sistema taungya. Revista Árvore, v. 39, n. 5, p. 893-903, 2015. Disponível em: <http://dx.doi. org/10.1590/0100-67622015000500012>. Acesso em: 08 abr. 2018.

MENEZES, J. M. T.; van LEEUWEN, J.; VALERI, S. V.; CRUZ, M. C. P. da; LEANDRO, R. C. Comparação entre solos sob uso agroflorestal e em florestas remanescentes adjacentes, no norte de Rondônia.

Revista Brasileira de Ciência do Solo, v. 32, n. 2, p. 893-898, 2008. Disponível em: <https:// dx.doi.org/10.1590/S0100-06832008000200043 >. Acesso em: 09 abr. 2019.

MICCOLIS, A.; PENEIREIRO, F. M.; MARQUES, H. R.; VIEIRA, D. L. M.; ARCO-VERDE, M. F.; HOFFMANN, M. R.; REHDER, T.; PEREIRA, A. V. B. Restauração ecológica com sistemas agroflorestais: como conciliar conservação com produção: opções para Cerrado e Caatinga. Brasília: Centro Internacional de Pesquisa Agroflorestal, 2016. 266 p. 
MONTAGNINI, F. Los sistemas agroforestales y su contribución para la mitigación y adaptación al cambio climático. Edición Especial de la Revista Alcance, 24 p., 2012.

MONTEIRO, D. A.; PERESSIN, V. A. Cultura da araruta. In: CEREDA, M. P. Agricultura: tuberosas amiláceas Latino Americanas. São Paulo: Fundação Cargill, 2002, p. 440-447.

MOORE, P. L.; HOLL, K. D.; WOOD, D. M. Strategies for Restoring Native Riparian Understory Plants Along the Sacramento River: Timing, Shade, Non-Native Control, and Planting Method. San Francisco Estuary and Watershed Science, v. 9, n. 2, p. 1-15, 2011. http://dx.doi.org/10.15447/ sfews.2014v9iss2art1.

MOREIRA, J. C.; PERES, F.; SIMÕES, A. C.; PIGNATI, W. A.; DORES, E. de C.; VIEIRA, S. N.; STRÜSSMANN, C.; MOTT, T. Contaminação de águas superficiais e de chuva por agrotóxicos em uma região do estado do Mato Grosso. Ciênc. Saúde Coletiva. v. 17, n. 6, p. 1557-1568, 2012. Disponível em: <http://dx.doi.org/10.1590/S1413-812>. Acesso em: 12 abr. 2018.

MUELLER-DOMBOIS, D.; ELLEMBERG, H. Aims and Methods of Vegetation Ecology. Wiley: New York, 1974. 547 p.

NEPSTAD, D. C.; PEREIRA, C. A.; SILVA, J. M. C. A comparative study of tree establishment in abandoned pasture and mature forest of eastern Amazonia. Oikos, v. 76, n. 1, p. 25-39, 1996. Disponível em: <DOI:10.2307/3545745>. Acesso em: 13 out. 2015.

ODEKU, O. A. Potentials of tropical starches as pharmaceutical excipients: A review. Starch, v. 65, n. 1-2, p. 89-106, 2013. Disponível em: <http://doi.org/10.1002/star.201200076>. Acesso em: 04 jan. 2018.

OLIVEIRA, T. J. F. de; BARROSO, D. G.; ANDRADE, A. G. de; FREITAS, S. J. Consórcio de espécies nativas da Mata Atlântica com milho e feijão para revegetação de mata ciliar na região Noroeste Fluminense. Floresta, v. 46, n. 3, p. 315 - 324, 2016. Disponível em: <http://www.scielo.br/pdf/rarv/ v36n2/a10v36n2.pdf>. Acesso em: 08 fev. 2018.

PETIT, B.; MONTAGNINI F. Growth in pure and mixed plantations of tree species used in reforesting rural areas of the humid region of Costa Rica, Central America. Forest Ecology and Management, v. 233, p. 338-343, 2006. Disponível em: <https://doi.org/10.1016/j.foreco.2006.05.030>. Acesso em: 14 maio 2017.

PYWELL, R. F.; HAYES, M. J.; TALLOWIN, J. B.; WALKER, K. J.; MEEK, W. R.; CARVELL, C.; WARMAN, L. A.; BULLOCK, J. M. Minimizing environmental impacts of grassland weed management: can Cirsium arvense be controlled without herbicides? Grass and Forage Science, v. 65, p. 159 - 174, 2010. Disponível em: <http://DOI: 10.1111/j.1365-2494.2010.00735.x>. Acesso em: 15 abr. 2018.

REFLORA - Herbário Virtual. Herbário Virtual. (2017). Disponível em: <http://reflora.jbrj.gov.br/ reflora/herbarioVirtual/> Acesso em: 13 jul. 2019. 
RIBEIRO, K. T.; DE FILIPPO, D. C.; PAIVA, C. L.; MADEIRA, J. A.; NASCIMENTO, J. A. Ocupação por Brachiaria spp. (Poaceae) no Parque Nacional da Serra do Cipó e infestação decorrente da obra de pavimentação da rodovia MG-010 na APA Morro da Pedreira. Minas Gerais. In: SIMPÓSIO BRASILEIRO DE ESPÉCIES INVASORAS. 2005, Brasília. Anais... Brasília: [s.n.], 2005, p. 1-17.

ROHANDI, A.; BUDIADI; HARDIWINOTO, S.; HARMAYANI, E.; SUDRAJAT, D. J. Variability in morpho-physiology, tuber yield and starch content of several arrowroot populations in Garut district. AGRIVITA Journal of Agricultural Science, v. 39, n. 3, p. 311-323, 2017. Disponível em: <http:// doi.org/10.17503/agrivita.v39i3.1002>. Acesso em: 13 mar. 2018.

SANTOS, H. G.; JACOMINE, P. K. T.; ANJOS, L. H. C.; OLIVEIRA, V. A.; LUMBRERAS, J. F.; COELHO, M. R.; ALMEIDA, J. Á.; CUNHA, T. J. F.; OLIVEIRA, J. B. Sistema brasileiro de classificação de solos. 3. ed. Brasília: Embrapa, 2013. 353 p.

SANTOS, G. L. dos; PEREIRA, M. G.; LIMA, S. S. de; CEDDIA, M. B.; MENDONÇA, V. M. M.; DELGADO, R. C. Landform curvature and its effect on the spatial variability of soil attributes, Pinheiral-RJ/ BR. Cerne, v. 22, n. 4, p. 431-438, 2016. Disponível em: <http://dx.doi.org/10.1590/010477602 $01622042184>$. Acesso em: 14 maio 2017.

SECRETARIA DO MEIO AMBIENTE. SÃO PAULO [Estado]. Oportunidades para restauração de paisagens e florestas na porção paulista do Vale do Paraíba: Plano de Desenvolvimento Florestal Territorial para a porção paulista do Vale do Paraíba. Porto Alegre: Ideograf, 2018, 213p.

SEIFFERT, N. F. Gramíneas Forrageiras do Gênero Brachiaria. Campo Grande: Centro Nacional de Pesquisa de Gado de Corte, 1980, p. 1-71. (Circular Tcnica, n. 1).

SHINTU, P. V.; RADHAKRISHNAN, V. V.; MOHANAN, K. V. Pharmacognostic standardisation of Maranta arundinacea L. - An important ethnomedicine. Journal of pharmacognosy and phytochemistry, v. 4, p. 242 - 246, 2015. Disponível em: <http://archives/2015/vol4issue3/PartD/4-3-3 6.pdf>. Acesso em: 21 mar. 2018.

SILVA, R. F. B.; BATISTELLA, M.; MORANA, E. F. Socioeconomic changes and environmental policies as dimensions of regional land transitions in the Atlantic Forest, Brazil. Environmental Science and Policy, v. 74, p. 14-22, 2017. Disponível em: <http://dx.doi.org/10.1016/j.envsci.2017.04.019>. Acesso em: 11 jul. 2019.

SOARES, A. F. S.; LEÃO, M. M. D.; VIANNA NETO, M. R.; OLIVEIRA, S. M. A. C. Risk estimate of water contamination by pesticides used in coffee crops. Revista Brasileira de Engenharia Agrícola e Ambiental, v. 16, n. 4, p. 425-432, 2012. Disponível em: <http://dx.doi.org/10.1590/S141543662012000400013 >. Acesso em: 12 mar. 2019.

SOARES, A. F. S.; LEÃO, M. M. D.; FARIA, V. H. F.; COSTA, M. C. M.; MOURA, A. C. M.; RAMOS, V. D. V.; VIANNA NETO, M. R.; COSTA, E. P. Occurrence of pesticides from coffee crops in surface water. Ambi-Agua, v. 8, n. 1, p. 62-72, 2013. Disponível em: <http://dx.doi.org/10.4136/ ambi-agua.1053 >. Acesso em: 12 mar. 2019. 
SOUSA, G. F. de; OLIVEIRA, L. A. de; SILVA, J. F. da. Plantas invasoras em sistemas agroflorestais com cupuaçuzeiro no município de Presidente Figueiredo (Amazonas, Brasil). Acta Amazonica, v. 33, n. 3, p. 353-370, 2003. Disponível em: <https://dx.doi.org/10.1590/S0044-59672003000300002>. Acesso em: 12 mar. 2019.

SOUZA, F. M.; BATISTA, J. F. L. Restoration of semi deciduous forest in Brazil: influence of age and restoration design on forest structure. Forest Ecology and Management, v. 191, n.1-3, p.185-200, 2004. Disponível em: <http://www.lerf.esalq.usp.br/divulgacao/recomendados/artigos/souza2003. pdf $>$. Acesso em: 12 mar. 2018.

SWADIJA, O. K.; PADMNABHAN, V. B.; VIJAYARAGHAVA, K. Growth and yield of arrowroot intercropped in coconut garden as influenced by organic management. Journal of Root Crops, v. 39, n. 1, p. 67-72 67, 2013. Disponível em: <http://ojs/index.php/jrc/article/view/185/73>. Acesso em: 05 maio 2018.

TARGA, M. S., BATISTA, G. T. Benefits and legacy of the water crisis in Brazil. Revista Ambiente \& Água, v. 10, n. 2, p. 234 - 239, 2015. Disponível em: <http://dx.doi.org/10.4136/ambi-agua.1629>. Acesso em: 22 maio 2018.

TORRES, R. B.; MATTHES, L. A. F.; RODRIGUES, R. R.; LEITÃO FILHO, H. F. Espécies florestais nativas para plantio em áreas de brejo. 0 Agronômico, v. 44, n. 1, 2, 3, 1992. Disponível em: <http:// www.fundacaofia.com.br/gdusm/lista_florestas_brejo.pdf>. Acesso em: 22 maio 2016.

VIEIRA, I. C. G.; UHL, C.; NEPSTAD, D. C. The role of the shrub Cordia multispicata Cham. as a "succession facilitator" in an abandoned pasture, Paragominas, Amazonia. Vegetation, v. 115, n. 1, p. 91-99, 1994. Disponível em: <DOI: 10.1007 / BF00044863>. Acesso em: 08 abr. 2019.

WEZEL, A.; CASAgrande, M.; CEletTe, F.; VIAN, J. F.; FERRER, A.; PEIGnÉ, J. Agroecological practices for sustainable agriculture. A review. Agronomy for Sustainable Development, v. 34, p.120, 2014. <DOI: 10.1007/s13593-013-0180-7>. Acesso em: 10 jul. 2019.

WHELAN, C. J.; WILLSON, M. F.; TUMA, C. A.; SOUZA-PINTO, A. Spatial and temporal patterns of post dispersal seed predation. Canadian Journal of Botany, v. 69, p. 428-436, 1991. Disponível em: <DOI: 10.1139 / b91-059>. Acesso em: 12 abr. 2018.

Received in: April 9, 2019

Accepted in: July 31, 2019 